\title{
Pericardial Effusion Indicator
}

National Cancer Institute

\section{Source}

National Cancer Institute. Pericardial Effusion Indicator. NCI Thesaurus. Code C139046.

An indication as to whether there is effusion between the parietal and visceral pericardia. 